\title{
Illustration, Re-Enactment, Citizenship and Heritage of Contemporary Conflict: The Case of the Ebro (1938)
}

\author{
Francesc Xavier Hernàndez-Cardona ${ }^{1, *}$, Xavier Rubio-Campillo ${ }^{2,3, *}$, Rafael Sospedra-Roca $1, *$ D \\ and David Íñiguez-Gracia ${ }^{1, *}$ \\ 1 Department of Applied Didactics, Universitat de Barcelona, 08007 Barcelona, Spain \\ 2 Ramón y Cajal' Research Fellow, Institut de Recerca en Educació, Universitat de Barcelona, \\ 08035 Barcelona, Spain \\ 3 School of History, Classics and Archaeology, University of Edinburgh, Edinburgh EH8 9AG, UK \\ * Correspondence: fhernandez@ub.edu (F.X.H.-C.); xrubio@ub.edu (X.R.-C.); rsospedra@ub.edu (R.S.-R.); \\ diniguez@ub.edu (D.Í.-G.)
}

check for updates

Citation: Hernàndez-Cardona, F.X.; Rubio-Campillo, X.; Sospedra-Roca, R.; Íñiguez-Gracia, D. Illustration, Re-Enactment, Citizenship and Heritage of Contemporary Conflict: The Case of the Ebro (1938). Sustainability 2021, 13, 3425. https:// doi.org/10.3390/su13063425

Academic Editor: Cosme Jesús Gómez-Carrasco

Received: 25 February 2021

Accepted: 17 March 2021

Published: 19 March 2021

Publisher's Note: MDPI stays neutral with regard to jurisdictional claims in published maps and institutional affiliations.

Copyright: (c) 2021 by the authors. Licensee MDPI, Basel, Switzerland. This article is an open access article distributed under the terms and conditions of the Creative Commons Attribution (CC BY) license (https:/ / creativecommons.org/licenses/by/ $4.0 /)$.

\begin{abstract}
Historical illustrations give us hypothetical visual reconstructions of the past, which contribute to their interpretation, knowledge, and understanding. The progress of software for the design and production of images has optimized the possibilities of generating models of educational and understandable illustrations of spaces, facts, and concepts of the past. At the same time, promoting historical recreation activities allows us to obtain photographic and moving images of a historical nature, which can be integrated into image processing software. This paper describes the experience of the DIDPATRI group (Heritage Education, comprehensive museography and new technologies) the University of Barcelona with the Battle of the Ebro (Spanish Civil War, 1938), concerning the design of models/educational illustrations of the conflict. The developed actions show that, with well-defined criteria, support for recreation, and basic but highly educational software that is understandable and replicable, iconographic models can be obtained at a reasonable cost. The final result provides us with the possibility to understand the past in greater detail. The heritage of the conflict gives us the possibility to reflect, thereby directly affecting the formation of quality citizenship.
\end{abstract}

Keywords: educational illustrations; historical recreation; conflict heritage; citizenship; Battle of the Ebro; Spanish Civil War

\section{Introduction \\ 1.1. Images of the Past}

This study explores the possibilities of using next-generation digital educational illustrations and historical recreations to optimize our understanding of places, facts, concepts, and conceptual systems linked to the historical and archaeological heritage of contemporary conflicts [1,2]. The educational illustration is conceived as an active agent, not a passive or complementary resource, in the processes of knowledge communication and teaching-learning. The proposal goes beyond the simplest use (as an educational resource) of images from other times to explain or contextualize the past, as well as studies about generating images conceived as models, elaborated based on new technological developments, with an explicitly educational function. The exploration of the limits of next-generation educational illustration is developed from the heritage of contemporary conflicts and focuses on the case of the Battle of the Ebro (1938) [3] during the Spanish Civil War (1936-1939). Knowledge of this heritage, and its casuistics, is important from a citizenry perspective in order to enhance democratic values consistent with the principles established in the Spanish state by the Law on Historical Memory [4]. The considerations presented are based on a wide range of research and interventions in public archaeology, public history, and educational museography developed by the DIDPATRI research group 
(Heritage Education) of the University of Barcelona, at various sites and historical spaces of the Battle of the Ebro between 2007-2020.

Ebro saw the largest and bloodiest battle of the Spanish Civil War. The area saw a Republican offensive supported by foreign aid (international brigades, soviet planes, and armor) crossing the Ebro river and occupying a set of mountain chains. The Nationalist Army, supported by German and Italian troops and materials, launched a set of bloody offensives over three months to gain control of the mountains on the right side of the river.

The proposals are located in a border area that considers the generation of archaic historical illustrations from new computer-generated imagery (CGI) techniques: digital illustration, 3D, scanners, photogrammetry, matte painting, infographics, audio-visuals, and multisensory proposals concerning historical recreation activities [5-8]. The illustrationrecreation binomial, as an instrument to optimize the understanding of the heritage of the conflict from iconographic models, is combined with a strong educational component in order to foster peace and citizenship, alongside the terrible experience of the Spanish Civil War, whose long heritage still affects Spanish society.

\subsection{Why Is Illustrating the Past Important?}

In the spaces and episodes of the Battle of the Ebro, where DIDPATRI works, it was found that, for broad-spectrum users, understanding and interpreting historical or archaeological heritage spaces linked to conflicts was problematic, as the remains were usually fragmentary or decontextualized from the actual historical situations, functions, and human environments in which they had existed before. Empirical experience indicates that since it is not directly observable, the past is abstract, and interpreting historical, archaeological, or heritage sources presents problems, as the possibility of understanding the evidence is inversely proportional to the degree of contextualization, conservation, or integrity [9]. On the other hand, the significance of evidence may be limited if one does not have sufficient resources to relate new concepts to prior knowledge. The remains of buildings, anthropic modifications of the landscape, or the landscapes themselves, in relation to certain facts, are all the more difficult to interpret the lower their state of integrity and conservation is. This problem of understanding is evident in formal learning-teaching and in non-formal learning. Constructivist logic states that we all learn by following the same mechanisms and that we learn continuously [10]. The heritage comprehension problems experienced by schoolchildren are similar to those experienced by adults with limited training. In the face of this problem and the different cases that DIDPATRI worked on, several questions arose.

Can we develop prototypes and models of educational intermediation based on iconographic representations from the evidence of the past to contribute to meaningful learning? Can we use emerging technologies to generate contextualized and credible images of historical recreation practices? Can we use emerging digital technologies to create understandable, quality illustrations at an affordable cost, which are therefore easier to communicate? Can we define which types of representations (human, artefactual, action) should be added to an iconographic model to make a certain theme more understandable, such as architectural reconstruction or structures, processes, or historical facts?

Traditionally, images have been used to magnify, explain, or leave memories of characters, scenarios, myths, epic stories, facts, situations, or places. Twentieth-century Western societies systematized the concepts of iconology [11] and illustration [12-15] related to history and the history of art. However, in 21st-century societies, and despite the new possibilities provided by digital technologies, no systematic proposals have been made to help theorize and optimize the use of illustration as a relevant generator in past teaching and learning processes. Despite this, the emergence and evolution of digital technologies define a new horizon of usability, as they enable the generation of good-quality historical images at a reasonable cost. In this sense, the new form of historical illustration, with its different prototypes, variants, and models, allows the democratization of access to knowledge of the past. However, its success also depends on the criteria that are adopted in the 
elaboration of images and the selection of elements to be included in the model, depending on the type of fact, materiality, concept, or conceptual system being represented. As a result, the experiences in the environment of the Battle of the Ebro contain possibilities for historical recreation as an auxiliary practice in obtaining/generating historical illustrations based on images of the past, which can be static or moving. The relationship between historical illustration and recreation is expressed based on protocols and prototypes and, concerning the complex heritage field of contemporary conflicts, by taking into account the civic dimension, which contributes knowledge and understanding for the formation of quality citizenship [16,17].

\subsection{Historical Illustration: The Power of the Image}

From ancient times to the present, historical illustration has been used to explain, re-create, show, exemplify, or legitimize, in an understandable way, facts, situations, or people of the past. From a conceptual and functional point of view, the Naram-Sin Sle, Trajan's Column, the Bayeux Tapestry, Delacroix's paintings, Viollet-le-Duc's drawings, Frank Hurley's photos, and the graphics of the Assassin's Creed games represent a similar objective: making visible and understandable facts, places, stories, or descriptions of a more or less true (or more or less imaginary) past come to life. The systematization of models of reconstructive educational illustration within the environment of archaeology and history developed throughout the second half of the 20th century, thanks to magazines such as National Geographic and others [18]. These publications were aimed at a broad audience, and sponsored archaeological missions, with an interest in reporting their efforts to the general public. Often, photographs of fragmentary and decontextualized remains were not enough to give an idea of places, heritages, and interventions. In this sense, throughout the 20th century, particularly from the 1970s, National Geographic generated unique iconographic models in the form of infographics, diagram blocks, stratigraphy treatments, teaching schemes, and representations of historical events, etc., which contributed to the idea of creating new representations of the past [19].

In history, the path borne by such journals met its counterpoint in pre-digital authors such as Giovanni Caselli [20], David Macaulay [21], Jordi Ballonga [22], Peter Conolly [23], and Stephen Biesty [24] who, from the 1970s, consolidated an explicitly educational type of illustration, with a reconstructive profile in history and archaeology.

At the end of the 20th and early 21st centuries, digital illustration experienced spectacular development from, above all, computer games [25]. Moreover, in cinema, 3D recreations demonstrated extraordinary possibilities [26-28]. From that moment, the recreation of historical or para-historical landscapes in cinema and video games was constant. The knowhow of digital illustration focused on ambitious and costly market projects, which fulfilled their goals thanks to large investments in 2D and 3D technologies. Digital illustration was also applied to teaching products, but they were made with limited resources and could not compete with the quality achieved in films and games, which were widely available on the market [29-31].

However, digital illustration, understood as an opportunity to build reconstructive and understandable images of the past from small investments, continued to grow $[32,33]$. Models of hypothetical 3D reconstructions of historical, archaeological, and heritage spaces, with more or less unequal results, flourished [34-36]. In this regard, it is worth noting the development of "virtual archaeology", which not only enhanced hypothetical reconstructions made from archaeological evidence and influenced the processes of socialization, but also helped in the development of various hypotheses [37-39]. At the same time, the development of photogrammetry and the use of scanning techniques, such as archaeological instruments, helped promote a 3D culture in archaeology $[40,41]$. However, the possibilities for socialization through these new technologies experienced little theoretical development [42].

At the same time, the possibility of digital illustration to interpret or explain the past, or to contextualize remains in a meaningful way, did not particularly reflect formal 
learning-teaching systems [43-45]. As new computer developments and mobile phones entered schools, democratizing access to images of the past using iconographic models eventually became an issue to consider [46-48]. Finally, it should be noted that computer advances enabled the launch of affordable 2D and 3D illustration programs that do not require excessive specialization. In turn, new methods of expression, such as conceptual art, and techniques such as matte painting, which are determinants in the generation of images of the past [49], opened up new possibilities.

However, the new technologies of the late 21st century experienced a Copernican twist, wherein, with minimal technical preparation, models of images from the past could be built by selecting all the elements necessary to make them understandable, depending on the object of knowledge.

\subsection{Re-Enactment and Living History}

In parallel, interest in the past and heritage steadily increased in post-industrial society. The emergence of historical consumption (heritage, museums, novels, reporting, games, tourism, etc.) impacted the markets, while social practices developed to serve as substitutes for time travel $[30,50,51]$. In this sense, living history activities, especially re-enactments, have grown rapidly in the 21st century [52]. The spectacular concentration of reenactors at Waterloo in June 2015 demonstrated the power of new historical immersion practices. Recreation was configured from the perspective of public history and archaeology as a space of interdisciplinary opportunity, requiring the coordination of different knowledge and techniques: manipulation of objects, expression, physical development, sensory environments, acoustic landscapes, etc. $[17,53]$. However, interest in recreational activities was not exclusively due to their social or playful dimension. They were interesting because they made the past visible and understandable, and they provided credible imagery, i.e., static illustration and quality motion pictures, and helped to contextualize fragmentary environments and visualizations of remains, processes, and situations that occurred in other time periods. In turn, experimental archaeology [54], which was also consolidated as a marginal discipline, shared its methodology and practice with historical recreation [55-57].

Re-enactment groups were soon used as assets in order to make heritage more dynamic and, in this sense, they became proactive elements in its protection and valuation. This cemented the practice of recreation, too, as one aspect of a valuable education [58,59]. The holistic nature of recreation pointed to the functional dimension of heritage support, a scientific practice related to experimental archaeology, as an educational activity, as it enabled the creation of empathetic situations $[60,61]$ and provided understandable visions of the past within a playful and civil dimension, thereby contributing to the formation of a citizenry that cares about its history. The images obtained from re-enactments, static or moving, can be integrated by computer graphics programs into 3D-generated landscapes, giving them increased vitality. The results of the new models, quality historical illustrations, opened up unforeseen possibilities for education, as huge volumes of credible images could be obtained inexpensively in order to illustrate the past.

\subsection{Hypotheses}

The hypotheses of the investigation arose from the problem that understanding conflicts from the past and their heritage depends on the degree of contextualization, preservation, and the integrity of the evidence. To address this situation, teaching-learning in formal and non-formal contexts requires intermediation resources. The main hypothesis, as presented in the developed cases, proposes that generating intermediation images based on digital illustrations obtained with the support of social practices of historical recreation and developing models that integrate knowledge can foster a better understanding of heritage. This can help to optimize their social and economic performance, as these images affect the formation of quality citizenship and the empowerment of cultural industries in heritage environments. 


\subsection{General Objectives}

The scientific, technological, and educational objectives are focused on three areas:

Educational discourse: define, generate, experiment with, and evaluate the characteristics of models and teaching prototypes of restitution/reconstruction/iconographic recreations of the past, conceived as intermediation artefacts, to contribute to the interpretation of typologies of heritage environments, and make them replicable in different types of media, museum artefacts, spaces, etc. Establish possible protocols in terms of processes, elements to be integrated into the models (depending on the object of knowledge), and design and use phases.

Historical illustration and technology: generate, test, and evaluate models of proposals for educational historical illustration based on emerging technological and cultural options [62] and on the combinations these allow: treatment of images obtained from geophysical prospecting; scanning and photogrammetry; 3D prints; historical recreation and significance in heritage spaces; 2D generation from matte painting and concept art; moving images; museum scenery; multisensory and expressive complements (sound, music, literature, plastic expression, etc.).

Historical recreation: experience and evaluate the possibility for historical recreation groups to generate digital images (photographic and moving) of people from another time and anthropic intervention scenarios linked to processes, facts, or concepts, considering the correct gender perspective. Create historical recreation groups comprised of university students to support research, outreach, and educational tasks from a learning service perspective.

Socialization of knowledge: propose digitally-based iconographic prototypes that are socially sustainable and economical in terms of their generation and transformation. Develop them in such a way that it is possible to replicate them in diverse contexts: publications, web environments, computer games, apps, museum ceilings, teaching materials, mobile telephony, augmented reality, virtual reality, museum scenery, 3D printing, etc.

Education in citizenship: implement interventions and cases investigated in the context of public archaeology, public history, and civic education, promote democratic values, and enhance wealth creation from sustainable use and enjoyment of heritage [63].

\section{Materials and Methods}

\subsection{Integrating Public Perspectives of the Past}

The interventions of the DIDPATRI group in the areas of the Battle of the Ebro (1938) and the Campaign of Catalonia (1938-1939) were initiated, for the most part, by archaeological excavations (2007-2020), taking into account experiences developed in the United Kingdom by the public archaeology movement [64-66], as well as the perspectives provided by public history, driven, above all, in the United States, by the National Council on Public History. Moreover, most interventions were carried out at the insistence of cultural associations of civil society, or local bodies of administration and governance. Both public archaeology and public history [67-70] influence the need to link heritage research with the social agents of the territory and to search for maximum complicity in relation to their knowledge, dissemination and safeguarding, including collaborative work and interdisciplinarity. On the other hand, public archaeology and public history emphasize the need to socialize, in a comprehensive way, the knowledge generated in research to influence quality citizenship, generate wealth, and protect heritage. These budgets fully coincide with those developed by DIDPATRI, whose researchers have extensive experience in the environment of heritage in formal and non-formal educational spaces, and who have developed numerous previous works on conflict archaeology [71,72].

In this sense, archaeological research into the surroundings of the Spanish Civil War did not involve relevant difficulties for the group [73]. However, there was a willingness to generate, from their interventions, a methodological practice to systematize experiences and allow for the development of a functional doctrine to address research and socialization actions related to the heritage of the conflict. In this context, the idea of enhancing 
models of educational historical illustration was key. The past cannot be seen directly, but nothing prevented us from generating understandable substitutes from images (static or moving) built on evidence. The research work around the Battle of the Ebro was broad and diverse. In all studies, the variables of historical illustration and historical recreation were always present, as well as the dynamic optimization of the socialization of knowledge, and education for peace and citizenship.

\subsection{Case Studies and Pilot Projects}

The historical-archaeological cases worked on or developed by DIDPATRI between 2007 and 2020 with regard to the surroundings of the Battle of the Ebro and the Civil War in Catalonia were as follows:

The archaeological survey and excavation of the Republican aviation airfields that intervened in the Battle of the Ebro (1938), involved in the museum design of the Republican Aviation Interpretation Center in Els Monjos, and the implementation of a memory space dedicated to the air forces of the Spanish Republic [74,75].

The sectoral archaeological excavation of the Ordal Battlefield (1939). The intervention led to the development of themed educational visits and the celebration of re-enactment activities and was established in collaboration with the civic entity Institut $\mathrm{d}^{\prime}$ Estudis Penedesencs (Vilafranca del Penedès, Spain) and the City Council of Lavern Subirats [76].

The intervention of educational museography all'aperto at two outdoor interpretation stations, at the Rosanes Airfield, La Garriga, and the Anti-Aircraft Refuge of La Garriga Station (1938). The intervention was developed in collaboration with the city council of La Garriga [77].

Archaeological excavation, historical studies, and museum interventions in the surroundings of the Battle of Raïmats in La Fatarella (1938, Battle of the Ebro) [78,79]. The intervention involved works of experimental archaeology, a remembrance facility dedicated to the XV Brigade/15 Mixed Brigade [80], teaching materials and guided tours, annual days of historical recreation, and an ambitious program of historical illustration [81]. The initiative was developed in collaboration with civic and scientific agencies: the CSIC Heritage Laboratory (Higher Council for Scientific Research, Santiago de Compostela, Spain), the Lo Riu Civic Association, the City Council of La Fatarella, and recreation groups of the XV Brigade, Army of the Ebro, and Recreation-DIDPATRI, as well as the timely participation of researchers and students from the Universities of Glasgow and Edinburgh [82].

The archaeological excavation of the XIII International Brigade command post in Molí d'En Ferriol (Corbera d'Ebre) in collaboration with the Corbera d'Ebre City Council. This involved improving the cleanliness and adequacy of the space and the realization of historical recreation activities. [83]

The archaeological excavation of Pla de l'Obaga (Corbera d'Ebre), involving a remembrance facility dedicated to Major Robert Merriman of the Abraham Lincoln Battalion of the XV International Brigade [84]. Reenactment activities are regularly held on site. Activities were developed in collaboration with the Corbera d'Ebre town hall and the Poble Vell civic association.

A memory intervention (Flix) involving a remembrance installation dedicated to the pontoon engineers of the People's Army of the Republic. The intervention involved collaboration with the Flix City Council, La Cana Cultural Association, and historical recreation groups (XV Brigade Recreation-DIDPATRI) [85].

A memory intervention at a command post of the XV Army Corps of the People's Army of the Republic (La Fatarella-Ascó). This involved the development of a remembrance facility dedicated to Lieutenant Colonel Manuel Tagüeña at a place where historical recreation activities have been organized. The intervention involved collaboration with the Flix City Council and La Cana Cultural Association, and regular annual activities with historical recreation groups (XV Brigade Recreation-DIDPATRI) [80].

The design of an executive museum project within an air raid shelter in Torre Balldovina de Santa Coloma de Gramenet, in collaboration with the city council. 
The generation of ideas and the development of educational museography for the Cunit coastal fort, in collaboration with the Cunit City Council. On-site historical recreation activities are regularly carried out with the XV Brigade and Recreation-UB-DIDPATRI recreation groups.

The design of an executive project and construction management of the Interpretation Center of the Hospital del Molar (El Molar), which collects extensive museography related to surgery and war health. This included an ambitious audio-visual project based on the collaboration of historical recreation groups [86].

\subsection{Methodology and Work Plan}

The methodological references that influenced most interventions had an interdisciplinary orientation, but the structural features of research from an educational point of view gave prominence to archaeology and history, understood in the context of public history and public archaeology [87]. The interventions in heritage environments were at a crossroads between the disciplines responsible for learning and teaching and those that defined the content (factual and procedural) used in the heritage environment.

In the educational dimension, which is discussed in this paper, the intention was to generate reconstructive iconographic models of an educational nature, depending on the object of knowledge (trench, fortification, combat, artifact, etc.), which allowed us to understand-through the heritage evidence-spaces, concepts, processes, or situations. The central research technique corresponded with a methodology for the design of teaching models and prototypes, complemented and reinforced by the experimental technique, and the whole experience also integrated triangulation (various perspectives of analysis and assessment by diverse agents in time and space). From the point of view of educational research, the interventions had qualitative-comprehensive components and were carried out in collaboration with the different actors involved (teaching and cultural industries). The interventions were mainly based on a qualitative methodology oriented towards decision making and transformation. Although the educational institutions involved were schools, the research process occurred outside the classroom. In this sense, the research was also understood in a non-formal context, with strong social repercussions [88].

Part of the research was presented on an empirical basis, in terms of the design and evaluation of iconographic models, as it was based on products that could be tested and contrasted with the possibility of understanding and functionality. Building an iconographic doctrine involved a technical challenge that affected the problem of understanding the past. The information options (iconic requirements, cartographic, etc.) that drove the proposals were important, but the educational feasibility was also related to the possibility of emerging technologies and the opportunity to combine them. From this perspective, the use of historical recreation to obtain images of the past that could be used didactically was important. The educational feasibility was conceived as the sum of the techniques that create an environment for the study of a certain heritage object and the socialization of its knowledge (e.g., through georadar imagery, scanning, photogrammetry, hypothetical $3 \mathrm{D}$ reconstructions, digital printing, museography, matte painting, and conceptual art to contextualize the environment, and historical recreations to create models of the environment, etc.). The interaction between techniques and formats facilitated the generation of synthesized digital images, both static and moving, that enhanced and enabled viewers' understanding thanks to the different viewpoints provided by the iconographic models.

On the other hand, options with interactive development possibilities and greater playful and educational capacities were considered so that the formal design of iconographic proposals took on greater prominence. In this sense, the empirical-experimental dimension was considered to be an important component in the overall articulation of interventions, their content, and the resulting images that enabled their usability. Regarding the purpose of the investigation, this was considered in the field of applied research, as its purpose was to resolve practical problems and optimize strategies and resources. However, we can also consider, in the same educational context, the dimension of basic research, as proposals of 
general and universal validity were generated. The rules of usability or comprehensibility, extracted from iconographic prototypes, should enable the creation of replicable models of the most different realities to facilitate the understanding of heritage.

The set of actions and initiatives were part of what is generically considered action research and, from this perspective, we conducted assessments of the actors involved using surveys; we assessed the satisfaction of the public using satisfaction questionnaires; we used comprehensibility questionnaires to assess the teaching, monitoring and study of student cases; and we assessed the influx of users and the public via outreach and recreation initiatives organized around the investigated sites, which were either museographed or disclosed.

\section{Results}

\subsection{Virtuous Triangle of Educational Illustration}

From 2010-2011, the socialization strategies of knowledge practiced by the group were perfected by advancing what we have come to call the "virtuous triangle" of educational historical illustration. In 2010, when DIDPATRI was incorporated as a doctrine of our research, we established the techniques upon which part of the strategies of representation and the socialization of knowledge would be based. Three fundamental vectors were considered in the generation of educational iconographic models: (a) historical recreation, (b) 3D illustration and (c) matte painting illustration.

\subsubsection{A Doctrine of Socialization}

The different campaigns and projects developed around the Battle of the Ebro generated a scientific production base that is not considered in this article; however, the optics of Public Archaeology and History also involved productions, no less scientific, of empirical and axiological educational character at the service of the citizenry. Didactical articles were published, materials and outreach books were edited, two museums were designed (Republican Aviation Interpretation Center (La Garriga); Republican Health Interpretation Center, El Molar), trenches and forts (La Fatarella, Cunit) were rebuilt and museographed, and antiaircraft shelters were museumized (Santa Coloma de Gramenet; La Garriga); educational interpretation stations (La Garriga) were built, memory spaces were erected (Els Monjos, La Fatarella, Corbera d'Ebre, Flix) and, in a few years, almost a hundred historical recreation activities were held. However, the most relevant and structured aspect, the subject of this article, consisted of the generation of models and protocols of educational illustration in order to make what was being excavated or investigated more understandable.

The illustration focused mainly on the representation of historical moments and the explanation of the spaces in which these representations were housed. These considerations particularly came into play from 2010 onwards. Provisional iconographic representations of how the investigated environments were thought to have worked, or how things might have happened, were included within the different projects. This strategy proved successful as it not only helped to spread the initiatives among the population, but also contributed to archaeologists and historians making hypotheses about what they were working on. Socialization strategies also involved, in their second phase, with the audio-visual promotion of an educational nature, the direct musealization of the spaces investigated or the implementation of exhibition spaces in interpretation centers. The historical memory (important in the sites of the Spanish Civil War) was also enhanced by erecting monuments in memory of Republican fighters [80].

Empirical experience and theoretical reflection indicated that comprehensive illustration, often reconstructive, was the fastest and most effective way to communicate a certain historical context (material culture, place, space, site, character, artifact, historical fact, etc.). Of course, the option excluded, in principle, contexts related to mindsets, ideological systems or aspects of abstract thinking that were difficult, debatable or impossible to graphically represent. 
The objective was to generate an effective and sustainable model of educational illustration, i.e., it could run quickly, at a reasonable cost and use affordable resources and software. Naturally, this illustration had to be able to be reapplied in different contexts: publications, audio-visuals, museography, apps, QR codes, etc. From this perspective, the principles of "History as Representation" provided an epistemological basis solid enough to inform the proposal from a theoretical point of view, and in clear historiographic coordinates. It was clear that didactics helped to generate historical representations, and, in this sense, initiatives could be justified that would give teaching prominence to illustration $[89,90]$.

In all the sites and museum interventions in which it was possible, DIDPATRI carried out hypothetical 3D reconstructions. In some cases and spaces, it was even possible to use photogrammetry and virtual archaeological reconstruction. Collaboration with specialized technicians linked to the research group (Joan Ramon Casals; Guillem H. Pongiluppi; Mar H. Pongiluppi) was instrumental in obtaining spectacular results, which contributed to the accumulation of digital resources and the "library" of different projects that we generated.

\subsubsection{The Prominence of 3D}

In the experiences developed by DIDPATRI, spaces of very different magnitudes were reconstructed in 3D: forts, fortified lines such as those from La Fatarella to Ascó [81], as well as various entrenchment systems on the Ebro front. The educational power of these 3D images was extraordinary, and they were sufficient, on their own, to make understandable spaces that clearly presented the moments represented in them. The 3D reconstructions, on the other hand, provided indistinctly static or kinetic images, susceptible to the most diverse readaptations and reuses (in videos, apps or on the web). In general, action strategies involved the implementation of detailed 3D reconstructions from more or less broad sectors. The models developed, to optimize understanding, promoted the combination of $3 \mathrm{D}$ reconstructions and images from recreations, the introduction of furniture and machinery, and the incorporation of environmental elements (vegetation, waste, dominant climates, etc.).

Usually, we worked with the 3D Studio Max program, from which one can generate kinetic flights or select static views or focus on spaces that will later be developed by overlaying chroma recordings, characters and furniture, obtained from recreations and conditioned by matte painting. In this sense, 3D reconstruction generated almost infinite possibilities for iconographic development (Figures 1 and 2).

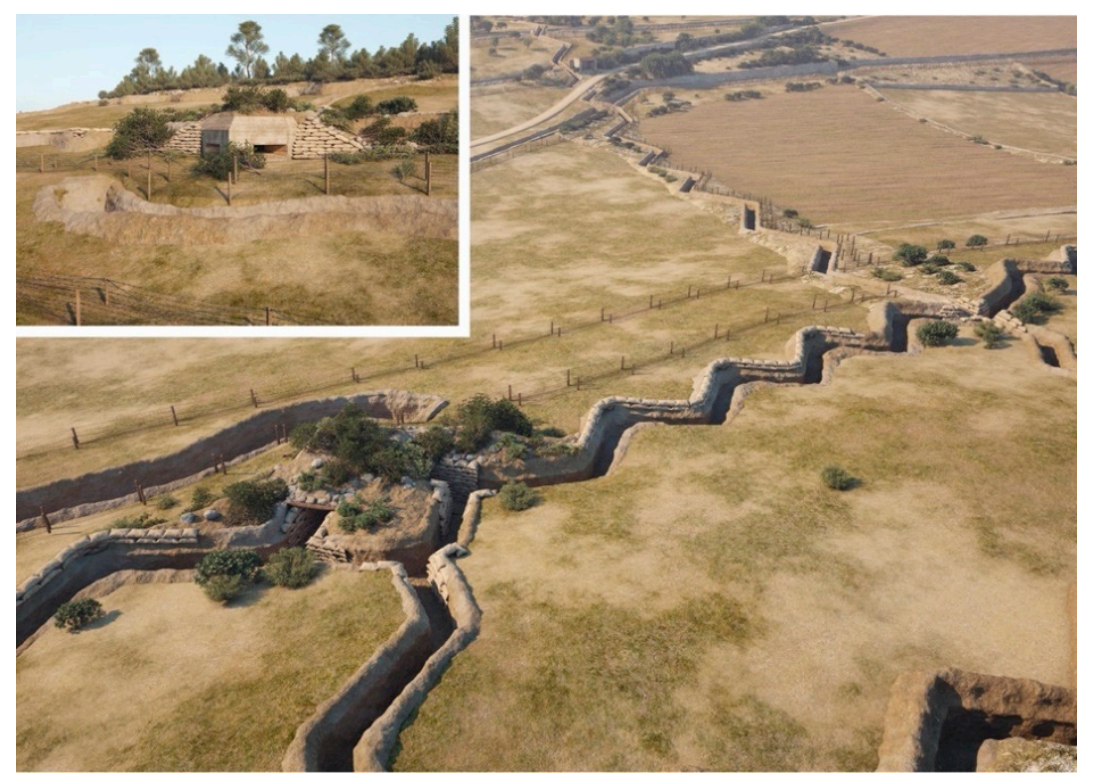

Figure 1. 3D reconstruction of the fortified line of La Fatarella, made with the 3D Studio Max program from archaeological, landscape, documentary and ethnographic evidence (J.R. Casals). 

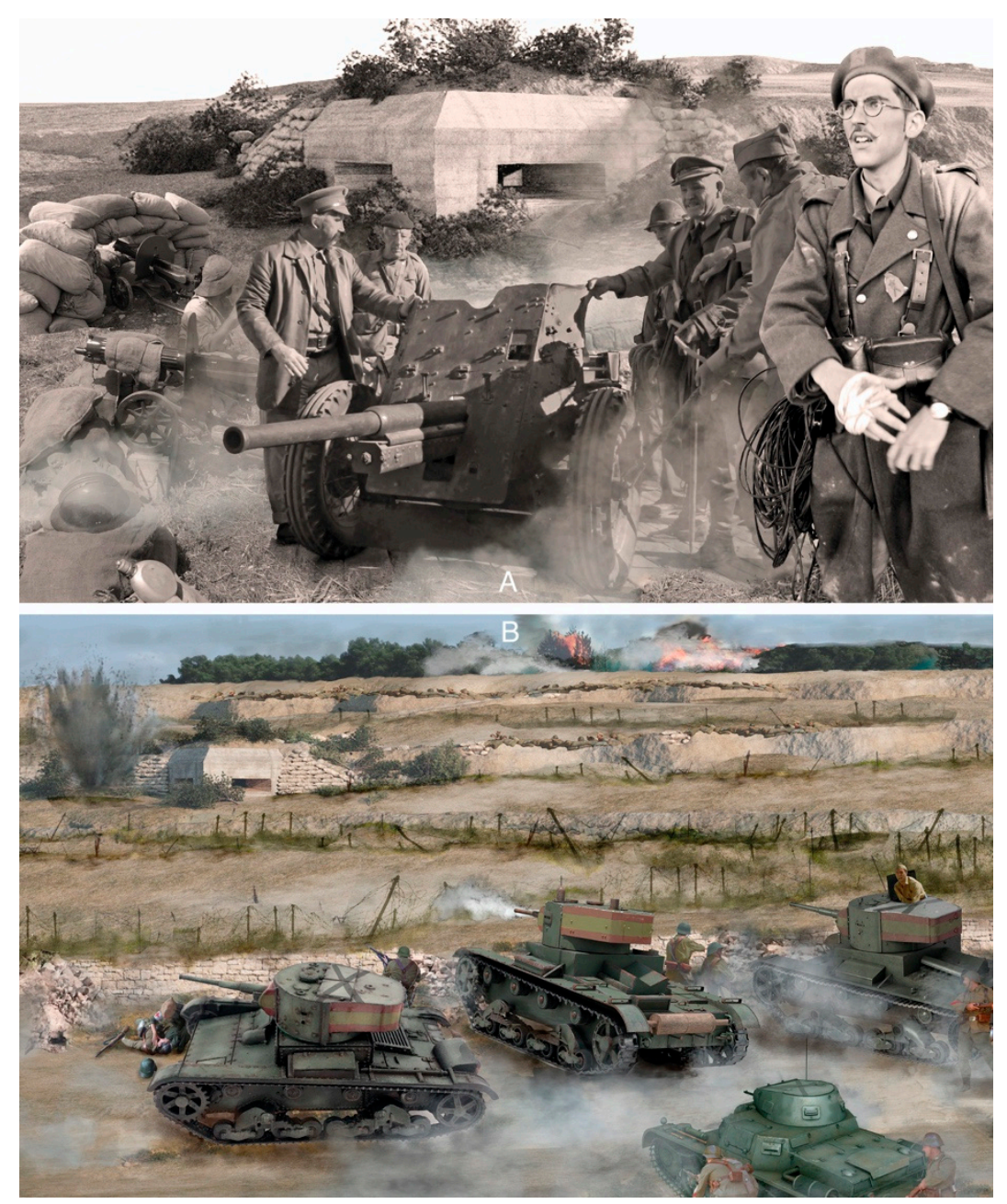

Figure 2. 3D reconstruction and historical recreation of a fort in the fortified line of La Fatarella and the Battle of Raïmats on 16 November 1938. (A) (upper) includes photographs and equipment of re-enactors, and (B) (lower) rectified photographic images. Both sets are finished using matte painting techniques (DIDPATRI UB).

\subsubsection{Recreation Options}

The virtuous triangle was conceived with a hypotenuse of historical recreation. Since 2005, the DIDPATRI group has collaborated and supported different projects by recreation groups existing in Catalonia: "XV Brigade"; "Lo Riu"; "Army of the Ebro" and structured its own recreation group: "Recreated UB-DIDPATRI", nurtured mainly by university students. Student mobilization was proposed in the context of service learning [91,92] whereas the university recreation group, along with volunteer students, supported cultural events in the investigated locations and also took a decisive role in obtaining images from recreations. With these initiatives, DIDPATRI became an organic component of the recreational movement. This position of commitment, and of recreating complicity, greatly facilitated the collection of images in the form of photographs and films of the most diverse moments and situations. Historical illustrations (static or kinetic), generated at a sustainable cost, as proposed by civic volunteering, were reapplied in the most diverse contexts possible. In some cases, the images of re-enactors filmed in chroma could be overlaid against the diverse backgrounds generated using $3 \mathrm{D}$ reconstruction. This made possible the creation of good-quality audio-visuals, which are suitable for museums, audio-visuals, apps, etc.

DIDPATRI, in collaboration with the companies "Molècula SL" and "Alma Cubrae", systematically created audio-visual resources using 3D reconstructions, historical recreations and drone flights for exhibitions and heritage centers. It is worth noting, in this 
regard, the video on Health in the Second Republic, the center for the interpretation of the Health of the People's Army of the Republic of El Molar (Priorat), the video about Robert Merriman, commander of the Abraham Lincoln Battalion and the video of the "Fortí de Cunit", among others. On the other hand, the results were rigorous in that the recreators knew how to move in a congruent and truthful way with respect to the period they represented. In turn, the equipment and clothes they wore were generally correct, and their participation was always enthusiastic. In this sense, collaboration with historical recreation groups was a decisive strategic option for DIDPATRI (Figure 3).
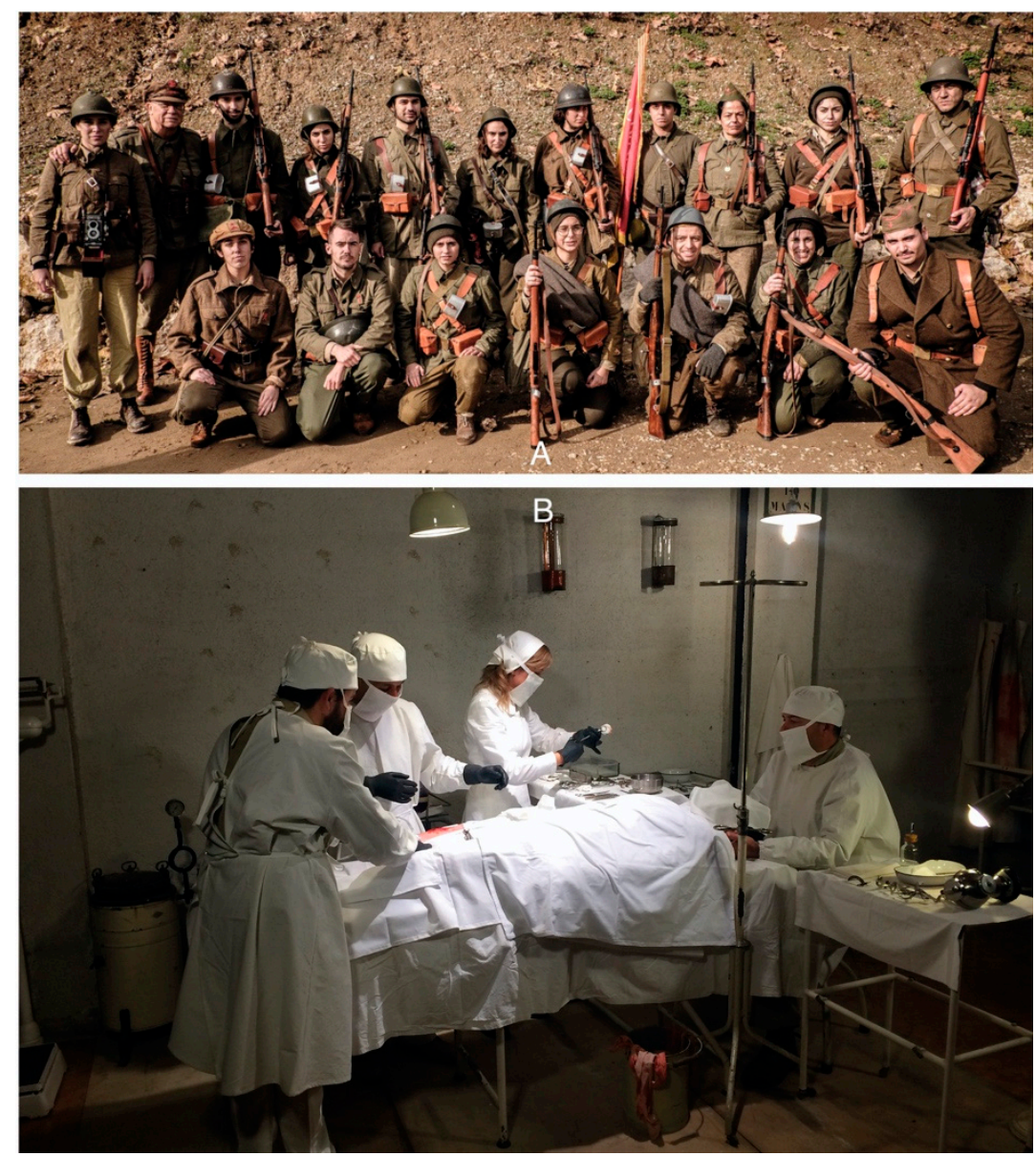

Figure 3. Recreation activities. (A) (upper) shows the DIDPATRI-UB historical recreation group, organized to support the research and transfer activities carried out by the research group around the Battle of the Ebro (DIDPATRI-UB). (B) (lower) presents a singular recreational activity that evokes a war surgery operation in a field hospital of the "Ejército Popular de la República". (Ejército del Ebro / Molècula SL).

\subsubsection{The Matte Painting Historical Illustration}

Finally, the virtuous triangle was complemented by matte panting of the illustrations (conceptual art). This involved the creation of 2D static digital illustrations that could be generated using the resources provided by the 3D reconstructions, the photographs supplied from the recreation groups, or both at the same time. Matte painting of the collages of photographs and various illustrations allowed us to obtain high-quality static images that were widely used in publications and museographies participated in or sponsored by DIDPATRI. In fact, in some cases, matte painting, which introduced human figures, furniture and context in 3D, optimized the understanding of the images and turned the sets into optimized models.

The three components of the triangle involved reasonable costs, which meant that quality illustration could be provided at affordable prices and that the doctrine was sus- 
tainable. The static or kinetic images obtained could be reapplied in diverse contexts: exhibition spaces, signage, audio-visuals, books, magazines, brochures, web, videos, apps, QR codes, augmented reality and avatars and scientific publications, and this made the efforts we employed profitable. On the other hand, the material generated by the different components of the triangle, in its digital form, had reasonable longevity, could accumulate, recompose and readjust, that is, be useful in different projects and functions, which gave it a unique utility. DIDPATRI applied the virtuous triangle to a great extent and with great success at the Republican Health Interpretation Center of El Molar (2019). A relevant part of the museum was developed through the use of matte painting and video resources developed thanks to the collaboration of recreation groups.

\subsection{Criteria in the Generation of Models of Educational Historical Illustration}

Through empirical experience, these different historical and archaeological interventions, and those of the different research processes developed, allowed us to establish functional criteria and protocols in terms of the generation of iconographic models of conflict environments. The different experiences helped us to generate, experiment and evaluate the variables that should guide the historical illustration design of the past, establishing, as the case may be, what should be displayed and how, as well as how to prepare the materials.

\subsubsection{Preference for Realistic Representations}

A model of educational illustration should not necessarily pretend to be an artistic manifestation. Its objective is not to try to excite via the use of a certain aesthetic, but to make the viewer understand, from an image or a singular intervention, a certain place, situation, process or action in the past. Certainly, the result of the recreation of a certain reality can provoke emotions, but these will not necessarily be subsidiaries of artistic expression.

Artistically oriented iconographic representations typically exist in an axiological or directly ideological/political environment, while educational representations respond to more empirical logic based on scientific knowledge. In this sense, realistic, or hyperrealistic, representation options are the optimal methods for the treatment or representation of a particular object of study in the past, as they are the ones that come closer to reality. Naturally, within this realistic concept, there may be more or less fortunate solutions or more or less aesthetic ones. In any case, a faithfully represented or reproduced space can excite, as much or more than an intervention developed based on creative criteria [93].

Often, depictions of archaeological spaces are developed aseptically, without furniture or human presence. These options are based on aesthetic criteria, or uncertainty about the furniture that existed at the time. From an educational point of view, spaces must be represented in context, even furniture and anthropic representations (whether verified or likely) in order to understand their functions, situations or processes. If there is no evidence about furniture or its uses, parallel situations or examples can be applied instead. On the other hand, digital images are easily correctable, and it is perfectly legitimate to present an illustration as a hypothesis, which is always provisional, and proceed with its correction when new information is obtained.

The struggle between didactics and supposed creativity, however, is barely evident in iconographic environments, and becomes more evident in museography, in museum scenery or in the musealization of monumental environments, in which diverse architects and creatives can leave random traces or remains outside the original image. Ultimately, in terms of heritage, this is already a nineteenth-century debate, with conflicting views, such as those of Ruskin and Viollet-le-Duc, but, in terms of strict didactics, the debate is not exactly the same.

\subsubsection{Structures and Artifacts}

In a sympathetic illustration, structures and the remains of structures (buildings, various constructions, ruins, landscape modifications, artifacts, etc.) are valued for their 
educational interest. In these illustrations, the representations and reconstructions, which are more or less hypothetical, are elaborated in 3D, particularly infographics [19,43], the "coupe-synthèse" (a good contribution of French radical geography), which involve the cutting of the 3D representation in order to allow viewers to observe interiors and oblique aerial views (since the photoplane can present excessive problems related to abstraction and interpretation). This type of cutting, which is usually applied to diagram blocks, is especially interesting as it allows us to understand the actual uses and functionality of spaces [94]. In the context of the Ebro conflict, La Fatarella's entrenched systems and forts [81] were particularly iconized, taking into account the mapping and teaching illustration solutions tested in recent decades to explain and show the forts of the Maginot Line. They also represented underground anti-aircraft shelters [95], the trench system and command post of Molí d'en Farriol (Corbera d'Ebre) [83].

In the same sense, oblique, static or kinetic aerial images, obtained from drones at different times during an excavation, are useful. For confined spaces (trench shelters, small anti-aircraft shelters, etc.), approximations can be used from photogrammetry that can allow for complementary iconographic developments. Some of the surveys carried out in $3 \mathrm{D}$ allow us, on the other hand, to perform animations, simulated flights and present the elements of study from the most diverse points of view and, in the case of heritage and conflict spaces, allow us to observe the visuals of the actors at any given time, which allows for a greater understanding of fields and battlegrounds.

Empirical experience, and the educational evaluation of illustration, advise that images of structures be contextualized, where appropriate, with human figures and with relevant furniture or machinery that are consistent with the time period being represented. This option obviously involves the creation of a model, and one cannot conceive of a structure without the uses for which it had been conceived, which involve artifacts and people. In the follow-up, it was found that both the young population and the non-specialized adult population are able to better understand a certain structure (trench system, shelter, fort, etc.) when it is displayed from a diagram block that makes visible a contextualized interior with furniture and people. The understanding is much greater than that achieved from a 2D planimetry of the structure and its sections. Regarding the use of colors and textures, the recommendation is that the colors and textures that are closest to reality should be used.

Of course, the situation is different when the target horizon is the scientific or technical community itself, which has the ability to interpret any type of information or mapping record from an excavation or description. However, when the archaeologist faces a threedimensional hypothetical reconstruction, he is also forced to consider hypotheses that were not necessarily raised beforehand. For decades, archaeology has operated with 2D representations, and archaeologists often do not have enough agility to hypothesize height, although the introduction of techniques such as photogrammetry has sought to correct this anomaly. Regarding the images obtained by photogrammetry and scanners, experience shows that, in some cases, they have an educational interest, but they generally show images of the present, which are often difficult to interpret as they present a fragmentary reality.

Similar logic should consider images of structures obtained from geophysical prospecting (gradiometer and georadar). In interventions such as the Ebro, this type of machinery was used on several occasions, and its use was especially useful for locating structures. In principle, images generated from georadar are difficult to use when explaining elements to broad audiences but are useful for developing or documenting iconographic teaching proposals. However, possibilities for educational transposition are under development. DIDPATRI's proposals and techniques were developed to optimize, from an educational point of view, the images obtained by geophysical prospecting [96] and, in the future, it is very possible that surprising results will be obtained in this environment.

When it comes to rendering artifacts, the issues and options are similar. Strategies for jointly displaying exteriors and interiors have been developed from multiple elements. It should be noted, in this regard, the great results obtained by virtuosos such as Biesty [94], 
despite the use of fully analogous craftsman techniques. Some of DIDPATRI's interventions in the Battle of the Ebro environment used sectioned artifacts to better explain their characteristics and possibilities (using cuts or sections of ambulances, trucks, tanks, aircraft, etc.).

\subsubsection{Representation of the Human Figure}

The representation of the human figure is essential to contextualize uses and make illustrations of structures, furniture, processes and actions understandable. In any historical representation, humans are directly or indirectly the object and subject. The interactions between structures, furniture, artifacts and the human factor are inseparable and cannot be conceived in isolation. This interaction generally typifies educational iconographic models even though it may be nuanced by the characteristics of the study object. The information provided on the appearance of humans should be as accurate as possible. In some cases, based on supposedly aesthetic or axiological criteria, certain designers obviate the representation of the human figure in archaeological-historical illustrations and scenery, under the pretext that they are of debatable taste. From an educational point of view, which aims to reproduce the coherence and consistency of moments and places of the past, the presence of the human figure is essential. The built-in human figure must be reproduced rigorously in terms of attire and equipment, and also in terms of physical appearance. The iconographic options developed by DIDPATRI in the Ebro Battle environment have opted for realistic or hyper-realistic options, often generated from recreations [81,97]. To produce human elements that could respond to the most diverse iconographic needs, a large digital library was implemented, with thousands of images, generated from photographs and videos from the historical recreation activities the group participated in. These images, using Photoshop and with composition criteria based on the matte painting technique, enabled very correct realizations to be produced. In general, DIDPATRI illustrations were developed in color, as colors also involve historical information (e.g., in relation to uniform equipment and human aspects). However, in some cases, black and white were also used, as in the imagination of many people predominates a perception about the Civil War from photographs and period documentaries. Similarly, careful attention was paid to representing certain emotions or sensations consistent with the place, moment or action. In some cases, the human figures generated were applied directly, e.g., in the creation of museum scenery at a 1:1 scale, trimmed or, using vinyl, attached to polycarbonates or methacrylate. The use of illustrations to vertebrate or generate scenery gave very good results in museum installations such as those of the Cunit fort or those of Republican Health Interpretation Center of El Molar [86].

As we have indicated, re-enactors are essential to obtaining good images of people. In any case, continued dialogue with these re-enactors should be maintained to assess the possibilities and their needs. It is absolutely essential that the teams have the utmost historical rigor, that the recreators respond to the stereotypes they are required to represent, that they manage the equipment with ease and that they know the protocols of the movement and organization of characters they represent.

\subsubsection{Situations, Moments and Processes}

Heritage does not always materialize from sufficiently significant furniture or real estate structures. Often, important facts in the history of a society leave no tangible traces. In the case of the Battle of the Ebro, this casuistic was evident as numerous battles, situations or installations left no material traces, even though they may have been important in the development of the battle. In the face of these situations, educational illustration must also be considered hypothetically, and act in the same way as it does in the face of the hypothetical reconstruction of structures with evidence. All possible information on the fact, situation or process to be worked on (combat, process, concrete situation, etc.) should be collected and a hypothetical illustration on the subject developed. This illustration can be very important in giving non-abstract meaning to the subject and can become a relevant vertebral element of a museum intervention. In the environment of interventions around 
the Battle of the Ebro, ambitious illustrations were developed based on facts or processes that had few sources or materiality: aerial combat [95] the reconstruction of the "Iron Bridge of Flix"; the illustration of the "Battle of Raïmats" [81]. Educational illustration, in these cases, has a very clear mission of hypothesizing to provide visualizations of facts or processes that are not immediately visible or transparent (Figure 4).

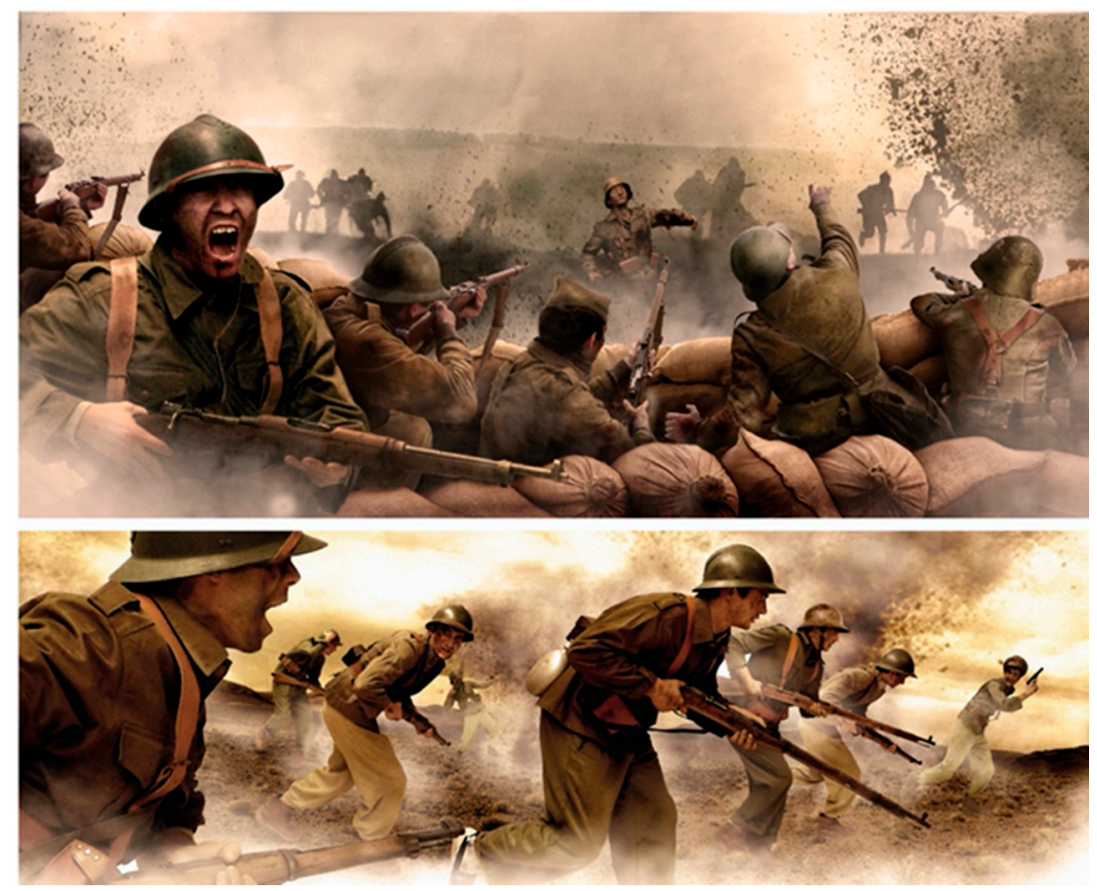

Figure 4. Historical illustration. Matte painting that shows the fighting of 16 November 1938, archaeologically documented in the trenches of Raïmats (La Fatarella). The illustration is made from photographs of historical recreations, articulated, treated, rectified and integrated using Adobe Photoshop (Mar H. Pongiluppi).

\subsubsection{Educational Synthesis Models}

The strongest point of educational illustration, as we have reiterated, is undoubtedly its ability to define models, which, taking into account reality, can transcend, complement and make history more understandable due to the complementary integration of "significant" elements. Unlike photography (a simple synchronous reflection of reality and, in this sense, of undisputed value), or more or less traditional illustration (usually created with artistic, aesthetic or directly ideological or political criteria), the model of educational illustration can define its own reality and "create" an image in which the most diverse elements or knowledge deemed appropriate are integrated to explain a fact, concept, conceptual system, artifact, structure or place. A photograph of a war hospital can show a situation at any given time, but in an educational illustration on the subject, it is the didact who decides what appears in the image: surgeons operating, the transfer of wounded, the implementation of transfusions, various tools, the arrival of the wounded, the presence of ambulances, etc. In this way, the artist can select or incorporate a set of elements that make a theme globally understandable and that configure an authentic educational landscape that can be inspired by a specific reality, or by various realities and fragmentary, diacritical or non-coincidental information in terms of space and time coordinates. In this sense, the image constitutes a model that collects and incorporates what the didact deems representative and significant from the object of knowledge that is being represented and communicated, and has the capacity and possibility for reapplication in various strategies to enable the socialization of knowledge. Naturally, in the elaboration of these models, created from possible spaces and characters, the contributions of the $3 \mathrm{D}$ recreations and the added proposal of matte painting, made possible by recreational photographs, are very important. Ultimately, this is 
a process that should never be assimilated to a photographic fake, as its purpose is scientific modelling and, obviously, the resulting images are presented as models for educational illustration (Figures 5 and 6).
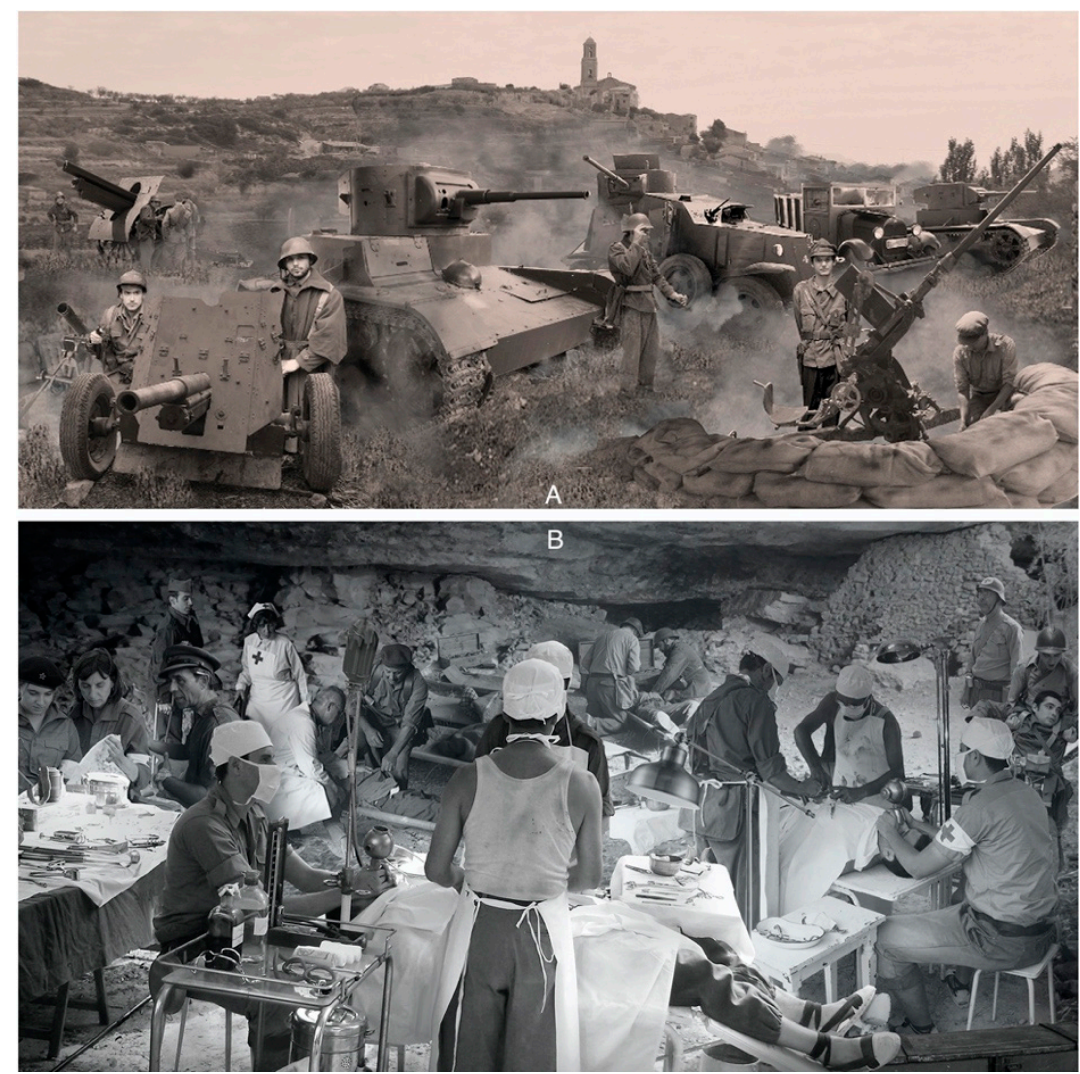

Figure 5. Models of educational synthesis. (A) (upper) synthesizes part of the heavy weapons used by the Republican forces in the Battle of the Ebro. A single image shows artillery and armor. (DIDPATRI-UB). (B) (lower) shows a synthesized vision of an improvised blood hospital inside a cave (DIDPATRI-UB).
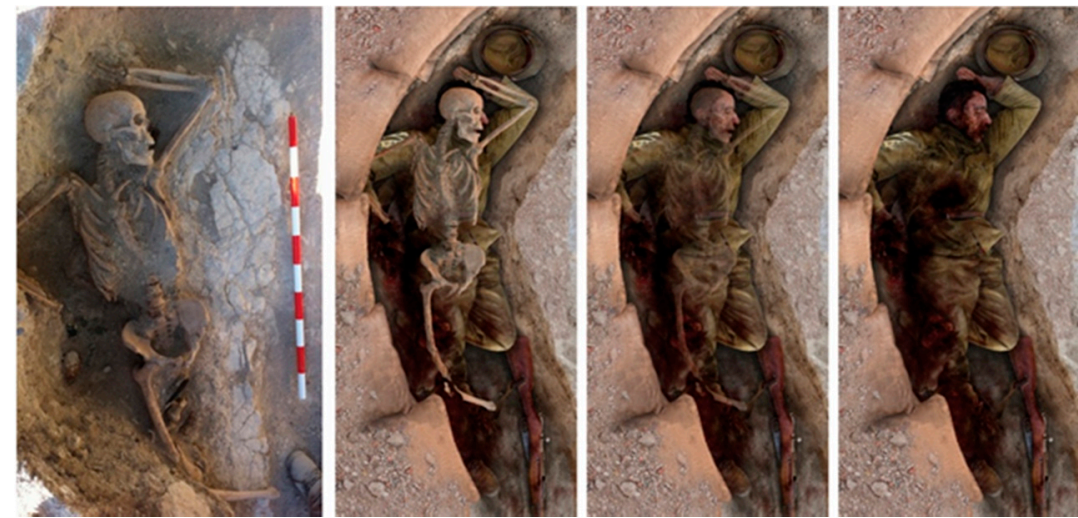

Figure 6. Skeletal remains of a Republican soldier located in the archaeological excavation of a trench in Raïmats (La Fatarella). Recreation of the wounds and the position of the soldier at the time of death, made with the support of a re-creator using Adobe Photoshop and based on archaeological evidence. (Mar H. Pongiluppi).

\subsubsection{The Weight of Memory}

In the case of the Spanish Civil War, and the Battle of the Ebro in particular, a hidden and erased confrontation of collective memory by the victors, it is important to promote 
policies of democratic memory from the perspective of civic formation. DIDPATRI has materialized the monumentalization of the investigated sites to convert them into memory spaces. To this end, a historical illustration proposal was also chosen, which, in this case, was sculptural: the realization of plates with bronze bas-reliefs that recovered the traditions of memory policies developed after the two world wars [98-103]. This proposal was chosen to represent realistic scenes of characters (or allegories) based on a sculptural aesthetic that also recovered Catalan novecentism. The location of plaques had very significant repercussions as they became space and time references, contributing to the democratic memory of the anti-phase struggle and the formation of quality critical citizenship. In total, up until 2020, five bas-reliefs dedicated to Republican aviation had been installed: dedicated to the fighters of the XV International Brigade and 15 Mixed Brigade; Pontoniers of the People's Army of the Republic; Lieutenant Colonel Manuel Tagüeña, commander of the XV Army Corps of the People's Army of the Republic; and Robert Merriman, commander of the Abraham Lincoln Battalion. The monuments acted as anchor points in the territories, contributing to the development of a dignified memory with quality intervention, and were soon used as landmarks for commemorative events and tributes based on good memory practices [104]. On the other hand, and from the point of view of the research group, memory policies served to resolve the dynamics of public archaeology and public history that had been initiated by the research, which included, in parallel, initiatives to socialize knowledge, and eventually ended with memory policies from a civic education perspective (Figure 7).
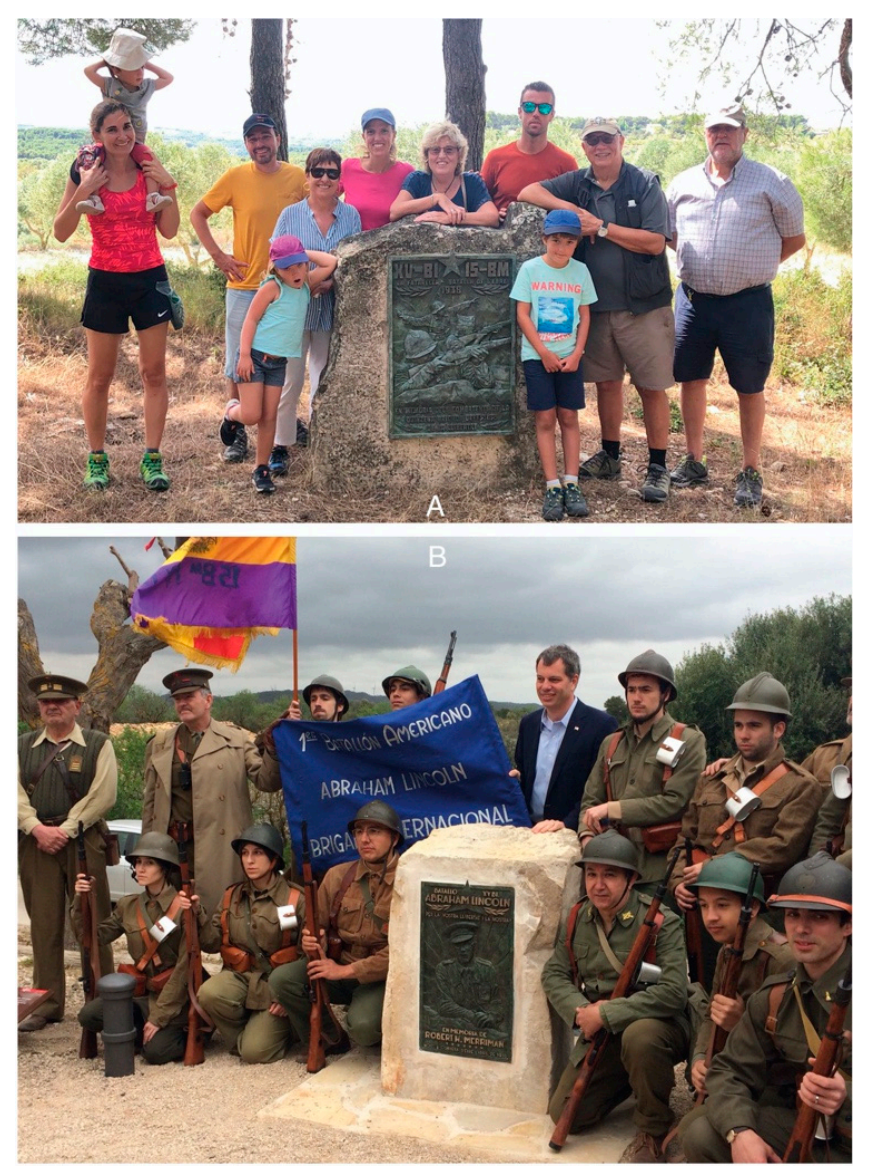

Figure 7. Commemorative monuments erected by the DIDPATRI research group. (A) (upper) shows a bronze plaque in memory of the combatants of the XV International Brigade/15 Mixed Brigade, located in Raïmats (La Fatarella). The space has become a benchmark for cultural tourism. (B) (lower) shows the inauguration of the bronze plaque in memory of Robert H. Merriman, commander of the Abraham Lincoln Battalion in Corbera d'Ebre, with the participation of reenactors and Mr. Marcos Mandojana, U.S. Consul in Barcelona. 


\section{Discussion}

\subsection{Digital Illustration: Doctrine of Intervention}

The iconographic proposals developed by the DIDPATRI group to represent the environment of the Battle of the Ebro were articulated, as additional components, in the holistic context of research and transfer. The iconographic proposals are summarized in the following decalogue, which discusses the experience and provides guidance regarding future research that may be carried out.

1. Illustration (through 3D, matte painting, infographics, scanners, 3D printing, photogrammetry, etc.) of the historical and heritage elements investigated in order to generate hypothetical reconstructions of places, processes and facts, in order to enable the socialization, in a comprehensive way, of the heritage locations under study, and also to facilitate the formulation of research hypotheses. Evaluate iconographic models based on interviews with teachers, and surveys and questionnaires intended for students or public users.

2. Collaborate with the social agents of the territory involved in the research, promotion, safeguarding and socialization of places and knowledge within the heritage environment. Work together with teachers and heritage educators in the area. Take into account the views and experiences of social actors as part of a qualitative approach and evaluation of iconographic models.

3. Document, from disciplinary archives and the literature, textual, cartographic or iconographic evidence. Take into account documentary resources in the development of iconographic models.

4. Explore ethnographic sources from the memories (oral history) of people involved (in facts and places) or their descendants. Illustrate episodes and descriptions referenced from oral history and memory. Utilize the collaboration of these people to add knowledge, value and safeguard the heritage.

5. Use advanced technologies in archaeological and historical research, such as geographic information systems, georadar, geophysical prospecting, aerial and satellite photo analysis, photogrammetry, etc., to propose iconographic models that take into account the information provided by technological environments and make this information understandable.

6. Intervene in the heritage/archaeological spaces investigated by promoting the consolidation, restitution or reconstruction of remains, facilitating the installation, on site, of intermediation artifacts or open-air museums and organize experimental archaeology activities, such as guided tours and historical recreation activities.

7. For museographical purposes, allow for the realization of exhibitions or the implementation of interpretation centers (or monographic museums) based on the principles of educational museography and by integrating subsidiary educational illustrations of the research.

8. Enhance the historical recreation activities, understood as socialization strategies, which are important both due to their empathetic burden, and because of the possibility for either static or kinetic illustration generation. Evaluate the activities of recreation groups based on surveys and questionnaires, among group members and among the user audience.

9. Understand that those sympathetic iconographic models, which can be reapplied in various contexts, contribute to the knowledge and safeguarding of heritage. In this sense, they are a factor of wealth generation, as they help to form quality citizenship and support cultural industries and quality tourism.

10. Memorialize, from the perspective of civic education, facts, places, moments and people in relation to the heritage investigated, in commemorative actions and by monumentalization through singular memorials (sculptures, bas-reliefs, plaques, etc.). Evaluate memory interventions using surveys and user tracking. 


\subsection{Effective Educational and Sustainable Production}

Traditionally, as we have indicated, the iconographic representation of situations of the past has been treated as a subsidiary of artistic expression when, in fact, this variable (subjective) is not decisive, as an image can be understood, or not, from a historical point of view. Moreover, this traditional form of illustration was generally subject to ideological or political criteria that did not necessarily meet the scientific criteria [16]. In recent times, new technologies have enabled us to generate understandable and realistic images of the past if the primary and secondary evidence correctly add up. The assembly of these new techniques implies, like never before, the possibility of generating static or kinetic illustrations in reasonably short times and with very limited costs compared to the old strategies based on artistic expression. This is an educational revolution in that the visualization of the past-the most direct way to understand it - can occur at any scale. Any site, small museum, excavation or monumental element can implement a quality iconographic program. What was previously reserved for large benchmarks, requiring large investments, is now available to virtually any heritage environment, and the impact is obvious on educational environments and on heritage and museum environments in which cultural and tourism industries are affected.

The scientific dimension, in terms of generating knowledge about iconographic models and the possibility of understanding them, is complemented by technological developments that have led to the incorporation of image creation techniques that, until now, were rarely used in the didactics of history. These image creation techniques can be complemented by sound, literary texts and sensitive landscapes. In this sense, the educational cluster that generates teaching materials for formal and non-formal teaching/learning environments may be an interesting recipient of iconographic models. Moreover, the field of museums and emerging cultural industries such as computer games (serious games, edutainment, audio-visual productions, etc.) have meant that a quality historical or heritage iconographic production is understood as a tertiary synthesis of primary and secondary evidence that can be applied interchangeably in dissemination, publications, museography, paneling, games, etc., and this can involve a real economic revolution that allows us to understand heritage and history, as dynamic elements in the cultural market and civic formation. Moreover, DIDPATRI's iconographic approaches have also been conceived based on their social impact, if the case study is taken into account. Understanding the history and heritage of the Spanish Civil War, an important topic for Spanish society, demands understandable images that help us to engage with a combination of different variables. In this sense, greater clarification of the conflict and its heritage (polyorcetic remains, productive structures, logistics spaces, forts, civil protection structures, repressive spaces, concentration camps, documents of all kinds, intangible heritage, landscapes, memory spaces, etc.) contributes to the debate on the balance of the conflict.

However, one of the problems that can arise from realistic iconographic models may be their malicious use. These educational images are ultimately fictional. They are not primary sources, but secondary or tertiary sources. However, iconographic models can be presented as or mistaken for real images. Nothing can prevent deepfake initiatives from proliferating and being applied in order to distort the past. These images represent a real risk, but we should not allow this to stop us creating images that send the viewer on a journey to the past just by looking at them. What will ensure the genuine nature of the images will not be their unfortunate use, but their correct use based on the ethics of scientific and transfer practices (Figure 8). 

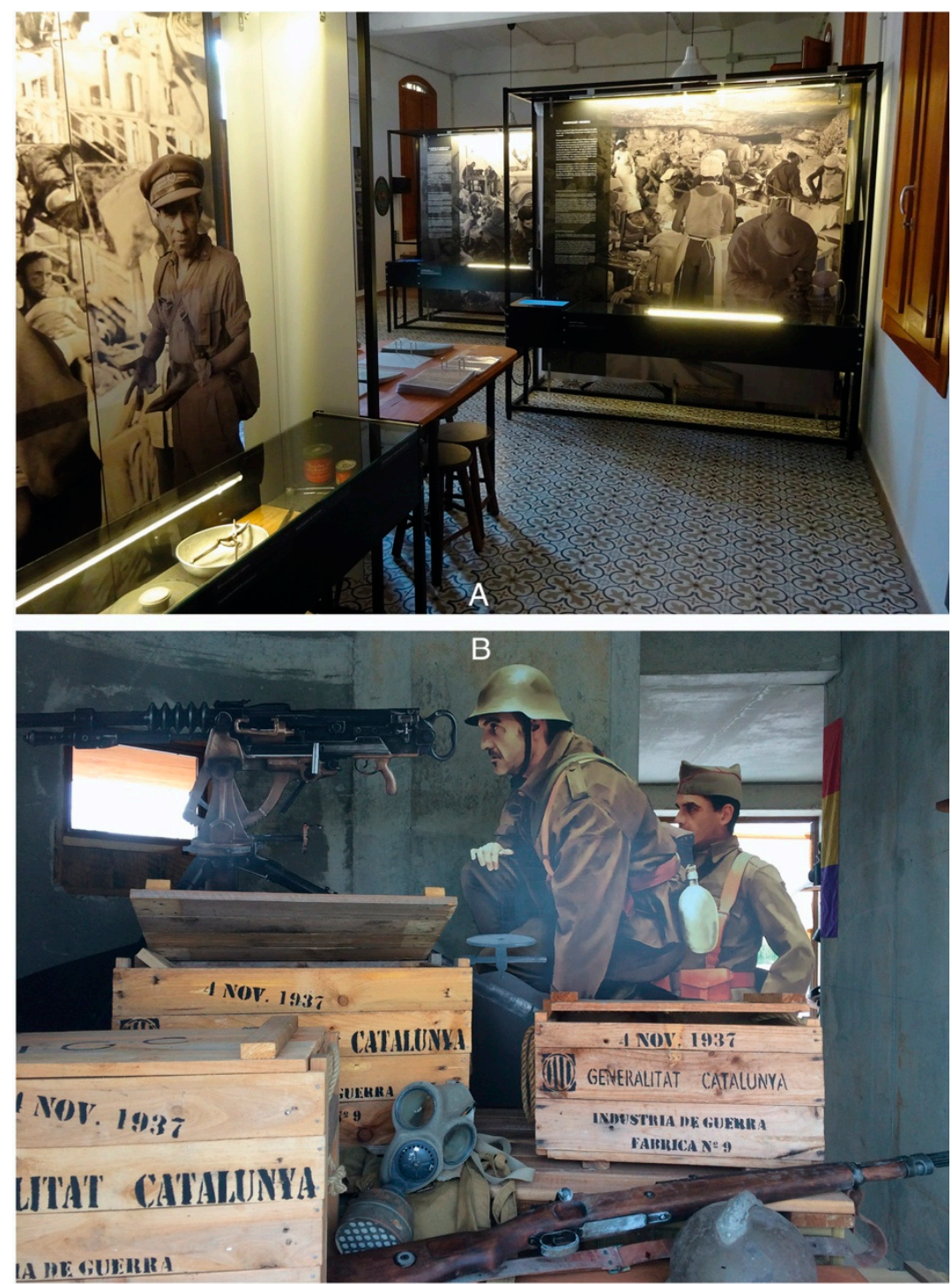

Figure 8. Museography that incorporates educational illustration resources. (A) (above) shows exhibitors from the Interpretation Center of the Hospital de El Molar (Priorat). (B) (lower) shows a scenography in the coastal fort located in Cunit. (DIDPATRI-UB).

\section{Results and Conclusions}

From the initiatives of educational historical illustration, re-enactment, citizenship and the heritage of the Battle of the Ebro conflict developed by the DIDPATRI group of the University of Barcelona, various conclusions can be drawn.

Historical and heritage models of educational illustrations have been defined and experienced, intended for broad-spectrum users, based on the integration of matte painting, $3 \mathrm{D}$ printing, and image libraries generated from historical recreations. The models have been developed to approximate different types of casuistics: archaeological structures, construction structures, factual artistic elements, production processes, sequences, processes, facts and historical moments.

It has been shown that, from basic CGI (computer-generated imagery) software, and emerging social practices in relation to history (re-enactment/living history), high-quality teaching and economic prototypes and iconographic models can be generated, produced and updated, with a reapplication capacity in various contexts, forms of media and functions: publications, museography, web environments, computer games, museography, mobile telephony, augmented and virtual reality (including avatars), etc. 
Models of iconographic representation were generated from empirical experience, in commemoration, in order to enhance the interpretation of historical-archaeological heritage spaces. The models are characterized by the possibility of them being understood by a wide range of recipients, from schoolchildren to citizens in general.

An approximation was generated regarding the technical and educational requirements of different types of media (including multimedia) to develop, using illustration and multisensory techniques, heritage spaces of conflict.

This contributed to the empowerment and implementation, as a cultural and economic asset (tourism and cultural industries), of heritage spaces by developing their understanding using iconographic models, as well as their on-site and virtual musealization.

Our research also contributed to the culturalization of society in the form of proposals that enhance the knowledge and integrity of heritage, while providing quality tools to boost heritage in the industrial and tourism dimensions.

Iconographic models were evaluated based on their impact on formal and non-formal learning and teaching environments, based on the qualitative considerations of the actors involved, public studies and user satisfaction questionnaires.

Protocols for collaboration and interaction between heritage environments and historical recreation groups were developed, as well as the ad hoc creation of recreation groups to enhance significant spaces related to the heritage of conflict.

The transfer of knowledge about the Spanish Civil War environment and, interchangeably, in formal and non-formal teaching/learning environments, contributing to the formation of quality citizenship, was increased due to the creation of iconographic teaching/learning options.

New forms of research and transfer were experienced in collaboration with social actors, through the dynamics of research action, service learning, public archaeology and public history. The cases discussed in this study contributed to the enhancement of environments that are intrinsically linked to heritage and memory.

Author Contributions: The work was conceptualized by F.X.H.-C. and X.R.-C.; the research was performed by F.X.H.-C., R.S.-R. and D.Í.-G.; F.X.H.-C. and R.S.-R. wrote the paper. All authors have read and agreed to the published version of the manuscript.

Funding: This research was funded by the Government of Spain. Ministerio de Economía y Competitividad (EDU2012-35299). 2013-2015: Desarrollo de estrategias y técnicas didácticas a partir del patrimonio y la arqueología del conflicto para la enseñanza/aprendizaje de las ciencias sociales y la historia. Ministerio de Ciencia e Innovación (EDU2016-76589) 2016-2019: Iconografía y recreación Histórica en la Didáctica del Patrimonio. El caso de la Guerra Civil Española. XRC's contribution was funded by the Ramon y Cajal programme (RYC2018-024050-I-Fondo Social Europeo-Agencia Estatal de Investigación).

Institutional Review Board Statement: Not applicable.

Informed Consent Statement: Not applicable.

Data Availability Statement: Not applicable.

Acknowledgments: Re-enactment groups: Recreació DIDPATRI; XV Brigada Mixta; Ejército del Ebro. Illustrators: Mar Hernàndez-Pongiluppi; Josep Ramón Casals Ausió; Guillem Pongiluppi-Hernàndez.

Conflicts of Interest: The authors declare no conflict of interest.

\section{References}

1. Schofield, J. Combat Archaeology: Material Culture and Modern Conflict; Bloomsbury Academic: London, UK, 2005.

2. Carman, J. Archaeologies of Conflict; A\&C Black, Bloomsbury Academic: London, UK, 2013.

3. Hernàndez-Cardona, F.X.; Feliu-Torruella, M.; Sospedra, R.; González-Sanz, M.; Wilson-Daily, A. Generación de iconografía didáctica a partir de recreación histórica y 3D. El caso de la Guerra Civil Española. Ensayos. Rev. Fac. Educ. Albacete 2019, 34, 67-82. 
4. Ley 52/2007, de 26 de diciembre, por la que se reconocen y amplían derechos y se establecen medidas en favor de quienes padecieron persecución o violencia durante la guerra civil y la dictadura. Articulo 1, Apartado 2. «BOE» núm. 310, de 27 December 2007. Available online: https:/ / www.boe.es/boe/dias/2007/12/27/ (accessed on 23 February 2021).

5. Dupré, S.; Harris, A.; Kursell, J.; Lulof, P.; Stols-Witlox, M. Reconstruction, Replication and Re-Enactment in the Humanities and Social Sciences; University Press: Amsterdam, The Netherlands, 2020.

6. Kouwenhoven, B.; Rappolt, M. Re-Enactors; Hotshoe International: London, UK, 2009.

7. Schneider, R. Performing Remains: Art and War in Times of Theatrical Reenactment; Routledge Taylor \& Francis: London, UK, 2011.

8. Schneider, R. Theatre E History; Macmillan International Higher Education: Heidelberg, Germany, 2014.

9. Reeves, K.; Bird, G.R.; James, L.; Stichelbaut, B.; Bourgeois, J. Battlefield Events: Landscape, Commemoration and Heritage; Routledge Taylor \& Francis: London, UK, 2016.

10. Pozo, J.I. El niño y la Historia; Ministerio de Educación y Ciencia: Madrid, Spain, 1985.

11. Panofsky, E. Studies in Iconology. Humanistic Themes in the Art of the Renaissance; Oxford University Press: Oxford, UK, 1939.

12. Dridon, A.N. Iconographie chrétienne. Histoire de Dieu; Nabu Press: Paris, France, 2011.

13. Mâle, E. L'art Religieux du XIIIe Siècle en France; A. Colin: Paris, France, 1958.

14. Van Marle, R. Iconographie de L'art Profane au Moyen Age et à la Renaissance et la Décoration des Demeures; M. Nijhoff: La Haia, The Netherlands, 1932.

15. Gombrich, E. The visual image: Its place in communication. In The Essential Gombrich: Selected Writings on Art and Culture; Phaidon: London, UK, 1996; pp. 41-64.

16. Apel, D. War Culture and the Contest of Images; Rutgers University Press: New Brunswick, NJ, USA, 2012.

17. Agnew, V.; Lamb, J.; Tomann, J. The Routledge Handbook of Reenactment Studies: Key Terms in the Field; Routledge: London, UK, 2019.

18. Carter, A. National Geographic: The Art of "National Geographic"; National Geographic Books: Washington, DC, USA, 1999.

19. Wiedemann, J.; Holmes, N. National Geographic Infographics; Taschen/National Geographic: Colonia, Germany, 2016.

20. Caselli, G. Life through the Ages; Grosset \& Dunlap: London, UK, 1987.

21. Macaulay, D. Rome Antics; HMH Books for Young Readers: Boston, MA, USA, 1997.

22. Hernàndez, F.X.; Comes, P. Barmi. A Mediterranean City through the Ages; Houghton Mifflin Company: Boston, MA, USA, 1990.

23. Connolly, P. Colosseum: Rome's Arena of Death; BBC Books: London, UK, 2003.

24. Platt, R.; Biesty, S. Stephen Biesty's Cross-Sections: Man-Of-War; Dorling Kindersley Publishers Ltd.: London, UK, 1993.

25. Champion, E. Critical Gaming: Interactive History and Virtual Heritage; Ashgate Publishing, Ltd.: Franham, UK, 2015.

26. Elsaesser, T. Film History as Media Archaeology: Tracking Digital Cinema; Amsterdam University Press: Amsterdam, The Netherlands, 2019; pp. 229-266.

27. Burgoyne, R. Introduction: Re-enactment and imagination in the historical film. Leidschrift Verleden Beeld. Geschied. Mythe Film 2009, 24, 7-18.

28. Gaudreault, A. Le Cinéma en Histoire: Institution Cinématographique, Réception Filmique et Reconstitution Historique; Méridiens Klincksieck/Québec, Éditions Nota Bene: Paris, France, 1999.

29. De Groot, J. Consuming History. Historians and Heritage in Contemporary Popular Culture; Abingdon Routledge: London, UK; New York, NY, USA, 2009.

30. Groot, J. Cultural Heritage and its Representations; Watson, S., Waterton, E., Eds.; Ashgate Publishing: London, UK, $2010 ;$ pp. 91-105.

31. Von Lünen, A.; Lewis, K.J.; Litherland, B.; Cullum, P. Historia Ludens: The Playing Historian; Rouletge: Oxon, UK; New York, NY, USA, 2019.

32. Economou, M.; y Pujol, L. Evaluating the use of virtual reality and multimedia applications for presenting the past. In Handbook of Research on Technologies and Cultural Heritage: Applications and Environments; Styliaras, G.D., Koukopoulos, D., Lazarinis, Y.F., Eds.; IGI Global: New York, NY, USA, 2011; pp. 223-239.

33. McMannamon, F. Digital Archaeological. In Encyclopedia of Global Archaeology; Smith, C., Ed.; Springer: Berlin/Heidelberg, Germany, 2014.

34. Hermon, S.Y.; Kalisperis, L. Between the real and the virtual: 3D visualization in the cultural heritage domain-expectations and prospects. Virtual Archaeol. Rev. 2011, 2, 59-63. [CrossRef]

35. Pujol, L. Arqueología, Museus i Ordinadors. Aproximació Semiòtica a l'ús de la Realitat Virtual per la Difusió de L'arqueologia als Museus. Ph.D. Thesis, Universitat Autònoma de Barcelona, Cerdanyola del Vallès, Spain, 2006.

36. Pujol, L. Realism in Virtual Reality applications for Cultural Heritage. Int. J. Virtual Real. 2011, 10, 41-49.

37. Forte, M. Virtual Archaeology: Re-Creating Ancient Worlds; H.N. Abrams: New York, NY, USA, 1997.

38. Evans, T.L.; y Daly, P. (Eds.) Digital Archaeology. Bridging Method and Theory; Routledge: London, UK, 2006.

39. Pujol, L. Does virtual archaeology exist? In Layers of Perception. Advanced Technological Means to Illuminate our Past, Proceedings of the 35th International Conference on Computer Application and Quantitative Methods in Archaeology, CAA2007, Berlin, Germany, 2-6 April 2007; Rudolf Habelt Gmbh: Bonn, Germany, 2008; pp. 101-107.

40. Miller, H.M.L. Archaeological Approaches to Technology; Elsevier Academic Press: San Diego, CA, USA, 2007.

41. Al-Ruzouq, R. Photogrammetry for Archaeological Documentation and Culture Heritage Conservation. In Special Applications of Photogrammetry; Carneiro Da Silva, D., Ed.; In Tech: Rijeka, Croatia, 2019; pp. 97-110.

42. Barceló, J.A.; y Vicente, O. Qué hacer con un modelo arqueológico virtual. Aplicaciones de la inteligencia artificial en visualización científica. Virtual Archaeol. Rev. VAR 2011, 2, 53-57. [CrossRef] 
43. Biosca, E.; Cantarell, E.; Sancho, M.; y Vinyoles, T. Reconstruyendo el pasado. Enseñar con tecnologías de realidad virtual. Iber Didàctica Cienc. Soc. Geogr. Hist. 2002, 31, 103-111.

44. Rivero, P. La arqueología virtual como fuente de materiales para el aula. Iber Didàctica Cienc. Soc. Geogr. Hist. 2011, 68, 17-24.

45. Hernández, F.X.; Romero, M. Imaginar la historia: Una cuestión de imágenes. Íber Didáctica Cienc. Soc. Geogr. Hist. 2014, 78, 7-14.

46. Jain, L.; Howlwett, R.J.; Ichalkaranje, N.S.; y Tonfoni, G. Virtual Environments for Teaching and Learning; World Scientific: London, UK, 2002.

47. Haydn, T.; y Counsell, C. History, ICT and Learning in the Secondary School; Routledge: London, UK, 2003.

48. Slator, B. Electric Worlds in the Classroom: Teaching and Learning with Role based Computer Games; Teachers College Press: New York, NY, USA, 2006.

49. Mattingly, D.B. The Digital Matte Painting Handbook; John Wiley \& Sons: Hoboken, NJ, USA, 2011.

50. Haffemayer, S.; Marpeau, B.; Verlaine, J.; Ory, P. Le spectacle de l'histoire; Presses Universitaires de Rennes: Rennes, France, 2012.

51. Petersson, B.; Holtorf, C. The Archeology of Time Travel: Experiencing the Past in the 21th Century; Archaeopress Archaeology: Oxford, UK, 2017.

52. Vaughan, R. History and Imagination: Reenacments for Elementary Social Studies; R\&L Education: Plymouth, UK, 2012.

53. Ansorg, R.A. Dokufiction? Living History? Histotainment? Der Archaeologe im Fernsehen zwischen Reenactment und Computeranimation; Diplomica Verlag: Hamburg, Germany, 2012.

54. Coles, J. Experimental Archaeology; Academic Press: London, UK, 1979.

55. Anderson, J. Living history: Simulating everyday life in living museums. Am. Q. 1982, 34, 290-306. [CrossRef]

56. Beck, A.S. Working in the borderland of experimental archaeology. On theoretical perspectives in recent experimental work. In Experimental Archeology, between Enlightenment and Experience; Petersson, B., Et Narmo, L.E., Eds.; Lund University: Lund, Sweden, 2011; pp. 167-194.

57. Mathieu, J.R. Experimental Archaeology: Replicating Past Objects, Behaviors, and Processes; Archeopress: Oxford, UK, 2002.

58. Goodacre, E.J.; y Baldwin, G. Living the Past: Reconstruction, Recreation, Re-Enactment and Education at Museums and Historical Sites; Middlesex Press: London, UK, 2002.

59. Jiménez, L.; Rojo, M.C. Recreación histórica y didáctica. Íber Didáctica Cienc. Soc. Geogr. Hist. 2014, 78, 35-43.

60. Fischer, B. Re-Enactment: Between Self and Other; Power Plant: Toronto, ON, Canada, 1990.

61. McCalman, I.; Pickering, P. Historical Reenactment: From Realism to the Affective Turn; Macmillan: Basingstoke, UK, 2010.

62. Caplin, S.; Banks, A.; Holmes, N. The Complete Guide to Digital Illustration; The Ilex Press Ltd.: Sussex, UK, 2003.

63. Flon, E. Les Mises en Scène du Patrimoine. Savoir, Fiction et Mediation; Hermès Science/Lavoisier: Cachan, France, 2012.

64. Moshenska, G. (Ed.) Key Concepts in Public Archaeology; UCL Press: London, UK, 2017.

65. McGimsey, C.R. Public Archeology; Academic Press Inc.: Cambridge, MA, USA, 1973.

66. Merriman, N. Public Archaeology; Routledge: London, UK, 2004.

67. Gardner, J.B.; LaPaglia, P.S. Public History: Essays from the Field; Krieger Publishing Company: Malabar, FL, USA, 2006.

68. Cauvin, T. Public History: A Textbook of Practice; Rouledge: New York, NY, USA; London, UK, 2016.

69. Howe, B.J.; Kemp, E. Public History: An introduction; Krieger Publishing Company: Malabar, FL, USA, 1986.

70. Demantowsky, M. Public History and School: International Perspective; Walter de Gruyter: Berlin, Germany, 2018.

71. Rubio, X.; Cela, J.M.; y Hernàndez, F.X. Simulating archaeologists? Using agent-based modelling to improve battlefield excavations. J. Archaeol. Sci. 2012, 39, 347-356.

72. Rubio, X.; Cela, J.M.; y Hernàndez, F.X. The development of new infantry tactics during early XVIIIth century: A computer simulation approach to modern military history. J. Simul. 2013, 7, 170-182. [CrossRef]

73. Hernàndez-Cardona, F.X.; Íñiguez-Gracia, D.; Gesalí-Barrera, D.; Rubio-Campillo, X. Arqueología, historia y didáctica de la aviación republicana en Cataluña (2001-2018). In Arqueología de la Guerra Civil y la Dictadura Española. La historia NO escrita; En Pérez-Juez, A., Morin, J., Eds.; BAR Publishing: Oxford, UK, 2019; pp. 49-61.

74. Arnabat, R.; Hernàndez, F.X. (Coord.) Estratègies de Recerca i Transferència del Coneixement Històric-Arqueològic. El cas de L'aviació Republicana (1938-1939); Llibres de Matrícula: Calafell, Spain, 2011.

75. Hernández-Cardona, F.X.; Rubio-Campillo, X.; Besolí, A.; Íñiguez, D.; Sospedra, R. Forgotten Pilots, Airfields and Aircraft: A Transdisciplinary Approach to the Memory of the Republican Air Force during the Spanish Civil War (1936-39). Public Archaeol. 2019, 18, 3-27. [CrossRef]

76. Rojo-Ariza, M.C.; Arnabat, R.; Cardona, G.; Íñiguez, D.; Fernández, I. Arqueologia de la Batalla de Catalunya (1939). (2010) Excavacions d'un tram de la línia defensiva L-3 a Subirats (Alt Penedès, Barcelona). In Ebre 38: Revista Internacional de la Guerra Civil (1936-1939); Universitat de Barcelona: Barcelona, Spain, 2010; Volume 5, pp. 193-216.

77. Coma, L.; Rojo, M.C. Arqueología y museografía didáctica en los aeródromos de guerra (1936-1939). In Ebre 38. Revista Internacional de la Guerra Civil (1936-1939); Universitat de Barcelona: Barcelona, Spain, 2010; Volume 4, pp. $165-177$.

78. González Ruibal, A. El último día de la batalla del Ebro. Informe de las Excavaciones Arqueológicas en los Restos de la Guerra Civil en Raïmats. La Fatarella (Tarragona); (CSIC-INCIPT) Informes y Documentos de Trabajo: Santiago de Compostela, Spain, 2012.

79. Hernàndez, F.X.; Rojo, M.C. Memòria dels Treballs D'excavació, Neteja i Reconstrucció als Raïmats, La Fatarella; Expedient 437K121N279/1-9191; Generalitat de Catalunya, Departament de Cultura: Barcelona, Spain, 2013.

80. Hernàndez-Pongiluppi, M. Escultures, memòria i didàctica de la Batalla de l'Ebre. In Ebre 38. Revista Internacional de la Guerra Civil (1936-1939); Universitat de Barcelona: Barcelona, Spain, 2020; Volume 10, pp. 123-140. 
81. Hernàndez, F.X.; Hernández-Pongiluppi, M. Ebre 1938. Imatges d'una Batalla; Angle Editorial: Barcelona, Spain, 2018.

82. Rubio-Campillo, X.; Hernàndez, F.X. Combined Arms Warfare in the Spanish Civil War: The Assault on the Republican Defence Line at Fatarella Ridge. J. Confl. Archaeol. 2015, 10, 52-69. [CrossRef]

83. Romero, M. Intervenció arqueològica a un refugi de comandament de les Brigades Internacionals durant la Batalla de l'Ebre. Resultats de les excavacions realitzades al Molí de Ferriol (Corbera d'Ebre). In Ebre38. Revista Internacional de la Guerra Civil (1936-1939); Universitat de Barcelona: Barcelona, Spain, 2018; Volume 8, pp. 163-176.

84. Hernàndez, F.X.; Íñiguez, D.; Wilson, A.; Sebares, G. Buscant Robert, H. Merriman. In Ebre38. Revista Internacional de la Guerra Civil (1936-1939); Universitat de Barcelona: Barcelona, Spain, 2020; Volume 10, pp. 169-181.

85. González-Sanz, S.; Hernàndez-Pongiluppi, B. Arqueologia pública, iconografía didáctica i memoria de la batalla de l'Ebre. In Ebre38. Revista Internacional de la Guerra Civil (1936-1939); Universitat de Barcelona: Barcelona, Spain, 2019; Volume 9, pp. 257-273.

86. Sospedra, R.; Boj, I.; Castell, J. El Molar. Museografía didáctica en un hospital de la Batalla de l'Ebre. In Ebre38. Revista Internacional de la Guerra Civil (1936-1939); Universitat de Barcelona: Barcelona, Spain, 2020; pp. 220-236.

87. Feliu, M.; Hernàndez, F.X. Didáctica de la Guerra Civil español; Ed. Graó: Barcelona, Spain, 2013.

88. Hernàndez, F.X.; Rojo, M.C. (Eds.) Museografía Didáctica e Interpretación de Espacios Arqueológicos; Trea: Gijón, Spain, 2012.

89. Chartier, R. Le monde comme representation. Ann. Économies Sociétés Civilis. 1989, 6, 1505-1520. [CrossRef]

90. Chartier, R. Au Bord de la Falaise: L'histoire Entre Certitudes et Inquietude; Albin Michel: Paris, France, 1997.

91. Jacoby, B. Service-Learning in Higher Education. Concepts and Practices; Jossey Bass: San Francisco, CA, USA, 1996.

92. Brown, D. Pulling It Together: A Method for Developing Service-Learning and Community Partnerships Based on Critical Pedagogy; Corporation for National Service: Washington, DC, USA, 2001.

93. Correia, M.L. L'image récréative: Des photos fantaisistes aux jeux virtuels. Société 2011, 111, 27-34. [CrossRef]

94. Biesty, S. Incredible Cross-Sections; Dorling Kindersley: London, UK, 1992.

95. Íñiguez, D.; Gesalí, D.; Casals, J.R. Sota les bombes. Els Atacas Aeris a Catalunya Durant la Guerra Civil; Angle Editorial: Barcelona, Spain, 2017.

96. Tamba, R. From Archaeological Prospection To Communication Using Learning Theory. Multi-Variable Maping and 3D Representations in Archaeology and Built Heritage. Ph.D. Thesis, Universitat de Barcelona, Barcelona, Spain, 2016.

97. González Ruibal, A. Volver a las Trincheras. Una Arqueología de la Guerra Civil Española; Alianza Editorial: Madrid, Spain, 2016.

98. Nora, P. Les Lieux de Mémoire; Gallimard: Paris, France, 1992.

99. Winter, J. Sites of Memory, Sites of Mourning: The Great War in European Cultural History; Cambridge University Press: Cambridge, UK, 2014.

100. Bird, G.; Claxton, S.; Reeves, K. Managing and Interpreting D-Day's Sites of Memory: Guardians of Remembrance; Routledge: London, UK, 2016.

101. Sherman, D.J. The Construction of Memory in Interwar France; University of Chicago Press: Chicago, IL, USA, 2001.

102. Crivello, M.; Garcia, P.; Offenstadt, N. Concurrence des Passés, Usages Politiques du Passé dans la France Contemporaine; Publications de l'Université de Provence: Aixen-Provence, France, 2006.

103. King, A. Memorials of the Great War in Britain: The Symbolism and Politics of Remembrance; Bloomsbury: London, UK, 1998.

104. Cottret, B.; Henneton, L. Du bon Usage des Commémorations. Histoire, Mémoire et Identité, XVIe-XXIe Siècle; Presses Universitaires de Rennes: Rennes, France, 2010. 